BULLETIN Bulletin hispanique

HISPANIQUE Université Michel de Montaigne Bordeaux

$113-2$ | 2011

Varia

\title{
El andalucismo nórdico de Luis Cernuda
}

\section{Miguel Ángel García}

\section{OpenEdition}

\section{Journals}

Edición electrónica

URL: http://journals.openedition.org/bulletinhispanique/1422

DOI: 10.4000/bulletinhispanique.1422

ISSN: 1775-3821

\section{Editor}

Presses universitaires de Bordeaux

\section{Edición impresa}

Fecha de publicación: 1 diciembre 2011

Paginación: 611-632

ISBN: 978-2-86781-793-9

ISSN: 0007-4640

\section{Referencia electrónica}

Miguel Ángel García, «El andalucismo nórdico de Luis Cernuda », Bulletin hispanique [En línea] 113-2 | 2011, Publicado el 01 diciembre 2014, consultado el 19 abril 2019. URL : http://

journals.openedition.org/bulletinhispanique/1422 ; DOI : 10.4000/bulletinhispanique.1422 


\title{
El andalucismo nórdico de Luis Cernuda
}

\author{
Miguel Ángel García \\ Universidad de Granada - España
}

Cernuda fait coïncider le début de la poésie contemporaine avec le Romantisme. Dans la tradition poétique espagnole il n'estime utile que l'exemple de Bécquer, qu'il définit comme un "andalou nordique", un véritable esprit romantique loin de toute vision superficielle et folklorique de l'Andalousie. C'est dans cette perspective que nous analysons la fascination qu'exerce sur lui le sud, propre au Romantisme nordique, que Cernuda, s'inscrivant à la suite des propositions d'Ortega y Gasset dans Teoría de Andalucía, éprouve dans les années 30.

Cernuda identifica el comienzo de la poesía contemporánea con el Romanticismo. En la tradición poética española sólo encuentra útil el ejemplo de Bécquer, al que considera un "andaluz nórdico", un espiritu verdaderamente romántico alejado de cualquier visión superficial y folklórica de lo andaluz. En esta linea analizamos la fascinación por el sur, propia del Romanticismo nórdico, que experimenta el Cernuda de los años 30 siguiendo asimismo los planteamientos de Ortega en su Teoría de Andalucía.

Cernuda identifies the beginning of the contemporary poetry with Romanticism. From this perspective, the only worthy example in the Spanish poetic tradition is Bécquer, whom he defines as "a Nordic Andalusian", a true Romantic spirit far from any shallow or quaint folk-lore views of Andalusia. Along these lines, this paper analyzes his fascination for the South, representative of the Northern Romanticism that Cernuda, following the approach of Ortega y Gasset in his Teoría de Andalucía, experiments in the 30's.

Mots-clés: Luis Cernuda - Poésie espagnole $\mathrm{XX}^{\mathrm{e}}$ siècle - Andalousie - Image romantique.

Bulletin Hispanique, Tome 113, nº 2 - décembre 2011 - p. 611 à 632. 


\section{HACIA UNA LECTURA ROMÁNTICA DEL SURREALISMO}

La nota con la que Luis Cernuda presenta su poética para la famosa antología de grupo del año 32, en rigor una "antología consultada» (Mainer, 2000: 339), no puede ser más sucinta y demoledora. Ni civilización, ni amigos, ni familia ni país escapan a la mirada inflexible que a la realidad dirige el deseo. Nos encontramos en el momento surrealista de esta escritura, en el turno de la verdad natural del sujeto frente a la mentira civilizada que impone preceptos y leyes desde fuera. No deja de ser una fábula amarga a la que nos tienen acostumbrados los poetas desde el Romanticismo: las querellas de una esencia interior, sagrada, contra el mundo que no está a la altura de sus arranques generosos. Todo ello está presente en estas palabras, de una dureza que pudiera parecer desconcertante sólo a primera vista, porque de inmediato permiten ser reconocidas como inspiradas por la rebeldía surrealista (y en el fondo romántica) contra la realidad, ya sea íntima o social, privada o pública:

No valía la pena de ir poco a poco olvidando la realidad para que ahora fuese a recordarla, y ante qué gentes. La detesto como detesto todo lo que a ella pertenece: mis amigos, mi familia, mi país. No sé nada, no quiero nada, no espero nada. Y si aún pudiera esperar algo, sólo sería morir allí donde no hubiese penetrado aún esta grotesca civilización que envanece a los hombres. (Cernuda, 1991: 752)

Las salidas que ofrece este choque desigual entre el yo y el sistema, el deseo y la realidad, el entusiasmo y la quietud (Marí, 1979), vienen a ser las mismas que puso en juego la estrategia romántica: o la anulación del deseo, su satisfacción última (la única posible) a través de la muerte, o la huida allí donde no haya llegado la civilización. Se confunden desde luego en las palabras de Cernuda: la muerte como huida final. Siempre, claro está, que aún queden fuerzas para saber algo, querer algo o esperar algo. Tal vez la brevedad contundente de esta nota, junto al desconcierto que también Diego pudo experimentar ante ella, hicieron que el antólogo finalmente la acompańase con dos extractos de los artículos que Cernuda había publicado sobre Paul Éluard (1929) y sobre José Moreno Villa (1931). Resultan bastante reveladores de la situación por la que atraviesa la ideología poética del autor en aquel entonces. En el primero se deja constancia del «misterioso dominio» que es la poesía y se contesta en términos "neorrománticos» o rehumanizadores al diagnóstico que del arte nuevo ha dado Ortega y Gasset en 1925: «sólo podemos conocer la poesía a través del hombre; únicamente 
él, parece, es buen conductor de poesía, que acaba donde el hombre acaba» (Cernuda, 1929a: 15). No se olvide que en La deshumanización del arte Ortega había escrito, al hablar de la separación nítida entre vida y poesía en los jóvenes artistas, que el "poeta empieza donde el hombre acaba» (Ortega, 1993: 35). Frente al antirromanticismo que Ortega descubre o inyecta en el arte nuevo, Cernuda advierte que el resultado poético es «fatalmente romántico».

La poesía pura es ya una reliquia que Cernuda ha dejado atrás, con el desagradable episodio de Perfil del aire, el libro inicial que ha visto la luz en el gongorino año del 27. La crisis surrealista ha abierto distancias con respecto al proyecto cultural que latía en la vanguardia racionalista, constructiva y modernizadora de los años 20 (Soria Olmedo, 1988; García, 2001). No hay más que leer el comienzo del artículo dedicado a Moreno Villa: "Los sistemas denominados para hacer reír, poesía pura o perfección de la poesía, una vez cumplida la tarea regocijante, han levantado su modesto vuelo de aves de corral» (Cernuda, 1931: 25). Otra vez Cernuda replica implícitamente a la deshumanización orteguiana al asegurar, a renglón seguido, que la poesía continúa encantando y amargando las horas de los hombres. No por casualidad recurre a una categoría como la de «inspiración», a la que asimismo había apelado Lorca a la altura de 1928 para contraponerla a la «imaginación» del poeta puro, en un momento en que decía estar cansado de la lección de Góngora y en que la poesía lógica o pura ya le resultaba insoportable (García Lorca, 1984). No por casualidad, tampoco, el origen y la finalidad de la actividad poética le parecen a Cernuda, como en el texto sobre Éluard, «tan misteriosos hoy, naturalmente». La poesía ya no se asienta, como en los días del purismo (Carnero, 1989), sobre el placer luminoso de la inteligencia, aunque tampoco los surrealistas españoles estuvieran dispuestos a caer en la "derrota del intelecto» preconizada por Breton.

El diálogo con estas ideas se extiende a la poética escrita para la antología que Diego publica en el ańo 34, muy distinta en su corte y factura a la del 32, como es bien sabido. Llevado por un afán de "exactitud sentimental», ahora Cernuda se pregunta si sigue siendo el mismo que escribió dos años antes aquellas palabras en las que hemos visto rezumar un clarísimo tono de rebeldía vital y poética. Y se responde que tal vez no, pero siente dentro de sí, imperioso y misterioso, el mismo impulso que le llevó a trazarlas:

Pienso hoy que si entonces creí odiar a mis amigos, a mis nulos amigos, es porque les amaba demasiado. $\mathrm{Y}$ en cuanto a mi país, no me aqueja tristeza o laxitud que no se aclare al pensar que allá en el sur las olas palpitan al sol sobre las arenas mías, sobre las arenas que 
sustentan desnudos cuerpos juveniles. Pero el sol, el mar, la juventud ¿no son los mismos en todo el universo? Entonces yo soy aquel, aquel mismo. (Cernuda, 1991: 581)

Obviamente quien escribe continúa siendo el mismo porque el conflicto entre realidad y deseo que aparecía velado apenas en el 32 ahora se hace explícito. El odio a la realidad antes lo llenaba todo. En este momento se habla, sin embargo, de la "tentativa» de ajustar o acercar el deseo a la realidad. Se sigue estando sustancialmente de acuerdo con las líneas escritas contra los amigos y contra el propio país, contra la realidad personal o privada y la realidad pública. Lo que ha cambiado es la posibilidad de trascender este odio confundiéndolo con el amor, el extremo con el que se toca, en el caso de los amigos, y de inmunizar o disipar el odio a lo público, en el caso del país, con los paisajes imaginarios que dibuja el deseo: allá en el sur, aunque a la vez se puntualice que el sol, la mar, la juventud son los mismos en todas partes. Hay una geografía real (las «arenas mías» en que los desnudos cuerpos se tienden al sol, la Andalucía natal por supuesto), pero sobre todo una geografía lírica del deseo, o mejor, del ajuste entre realidad y deseo. No necesita, al ser simplemente imaginaria, concretarse en ningún territorio preciso, si no es en el sol, la juventud y el mar. Ninguna complacencia de corto vuelo en el propio origen andaluz.

Lo decisivo es que la dialéctica entre realidad y deseo comienza a mostrarse con claridad, sin dejar de estar sugerida anteriormente y sin dejar de funcionar en los textos previos de Cernuda, en esta coyuntura en que la rebeldía surrealista revela su matriz romántica. No en balde en 1934, con la escritura de Invocaciones, como confiesa el propio Cernuda en «Historial de un libro» (1958), el cansancio de la «estrechez en preferencias poéticas de los superrealistas franceses» deja paso al interés por los poetas románticos ingleses y alemanes, y entre estos últimos, señaladamente por Hölderlin (Cernuda, 1978: 41-42). Sin ir más lejos, en la poética del 34 Cernuda cita a Byron, a Shelley, a Keats, a Goethe y al Hölderlin de Hiperión. Sin quedarse en el gesto revolucionario de los surrealistas franceses, así en la escritura como en la vida, Cernuda deriva hacia la dimensión romántica, de más largo recorrido, que alentaba en el surrealismo:

Luis Cernuda es posiblemente el poeta en lengua española que vio con más claridad el corazón romántico del surrealismo. [...] El surrealismo procuraba a la poesía espańola, carente de un movimiento romántico profundo, una verdadera oportunidad de saldar sus cuentas con las crisis líricas de la Modernidad. Desplazando el asunto 
a la significación moral, más allá de las modas y los estilos literarios, la rebeldía surrealista significa una reacción contra el orden de la sociedad burguesa, la crisis interna en el paradigma de la Modernidad que ya había impuesto el Romanticismo. (García Montero, 2000: 243)

La crítica, en efecto, ha venido subrayando el temperamento romántico de esta poesía. Al reseñar la primera edición de La realidad y el deseo (1936) Salinas acierta a ver que el título de la compilación "corresponde a la entraña del drama del hombre, tal y como se la plantearon los románticos. Realidad y deseo enfrentados, como el luchador y la fiera en el coso del mundo» (Salinas, 2001: 228). No sólo eso, porque también define este primer libro de libros como «la depuración más perfecta, el cernido más fino, el último posible grado de reducción a su pura esencia del lirismo romántico español» (p. 236). Pero el problema radica en que, para Cernuda, no hubo un auténtico Romanticismo español que saldase las cuentas abiertas por el paradigma de la Modernidad a las que acabamos de aludir.

Negar la existencia de un verdadero Romanticismo español equivalía a negar la existencia del nacimiento de la poesía moderna en Espańa. Basta con regresar al artículo citado sobre el surrealista Paul Éluard para comprender todo esto a la luz de la lectura romántica del surrealismo que lleva a cabo Cernuda en 1929. En él afirma que en España la palabra «romántico» no ha tenido significación:

La poesía española por exigencias o deficiencias, es lo mismo, de un temperamento exclusivamente verbalista, si así puede decirse, no ofrece ninguna fase romántica en su inagotable desierto de palabras, palabras, palabras. [...] Amamos o, mejor, se ama demasiado la palabra para ser románticos; sólo interesan las palabras, no la poesía. (Cernuda, 1929a: 16)

Insistimos en que para Cernuda la palabra romántico tiene «pleno sentido", como él mismo dice, "encima o debajo, a derecha o izquierda de la obra de Éluard». Sólo encuentra dos poetas románticos acaso en la tradición poética española: Garcilaso y Bécquer. A este último le dedica en 1935 un trabajo igualmente interesante para conocer su posición teórica ante el Romanticismo. La poesía moderna, aclara Cernuda, nace en la llamada época romántica. Pero junto al Romanticismo histórico del siglo XIX habla a la vez de un Romanticismo eterno, en la estela del famoso verso de Darío «Románticos somos... ¿Quién que es no es romántico?». El Romanticismo es algo así como un «espíritu diabólico» que se divierte asaltando a los individuos 
a través de los tiempos. No son pocas las desventajas que para el historiador de la literatura, obligado a periodizarla, derivan de la consideración del Romanticismo como una constante del espíritu humano. Hablar de «movimientos» literarios eternos desvirtúa la historicidad de la literatura. Sea como fuere, parece claro que Cernuda desea contarse entre los individuos agitados por ese espíritu diabólico del Romanticismo, señalando de paso que la transformación que ha originado en la conciencia moderna todavía no ha llegado a cerrarse. Más importancia tiene aún si cabe que establezca una línea divisoria en el interior del Romanticismo histórico. No son precisamente los poetas más populares los que traen la honda transformación para la poética moderna que acarrea el Romanticismo. Opone Shelley a Byron, Baudelaire a Hugo, Hölderlin a Schiller, aunque en este último caso no con la rotundidad de los dos anteriores.

Salta a la vista que Cernuda delinea a las claras la tradición romántica que considera más auténtica y a la que ha decidido acogerse. Nuestra tradición, no ya únicamente la romántica, era peligrosa en extremo, hasta el punto de resultar irreconciliable con ese Romanticismo verdadero que para él encarnan un Shelley o un Hölderlin: "No me extraña Hugo deletreando un romance del Cid; me sorprende Shelley con un tomo de Calderón entre sus manos ligeras» (Cernuda, 1935a: 69). La justificación de esta actitud se encuentra en la huida del verbalismo excesivo que, como se ha dicho, caracteriza a nuestra poesía. Para Cernuda el Romanticismo más hondo implica una liberación de la pompa, de lo ornamental. No sucedió así en nuestro Romanticismo. En el Duque de Rivas, Zorrilla o Espronceda hay una tendencia hacia lo "preconcebidamente poético, lo rico o lo nobiliario". La novedad de Bécquer es que con él se introduce la vida en la poesía, dando carta de naturaleza poética a ambientes y pasiones que para el gusto establecido rozaban con el prosaísmo. Obviamente esto hace de Bécquer nuestro primer poeta moderno, en el sentido baudeleriano del término, a mucha distancia del tono altisonante y preconcebidamente poético de nuestros otros románticos.

No corresponde a Cernuda el mérito de haber descubierto la modernidad de Bécquer, porque ya lo hicieron, cada uno a su modo, Unamuno, Machado y Juan Ramón Jiménez. Este último llama a Cernuda el más «sobrebecqueriano» de los jóvenes poetas del Veintisiete. Pensemos en la huella becqueriana, ya desde el título mismo, en Donde habite el olvido, publicado en 1934. Pero lo que importa es darse cuenta de que Cernuda se mira en el espejo del autor de las Rimas para construir su propia tradición poética romántica. La razón principal de la modernidad becqueriana estriba en «rechazar de la poesía todo lo que es ajeno al lirismo», sin caer en «los 
errores antipoéticos de los caudillos románticos españoles» (Cernuda, 1935a: 77). El Romanticismo español causó a nuestra poesía un daño irreparable porque no supo «libertarla a tiempo» de ese retoricismo tan propio de la tradición poética espańola. Bécquer, en la famosa reseña de La soledad, de Augusto Ferrán, apuesta por una poesía natural, desnuda de artificio, frente a la poesía magnífica y sonora, que se viste con todas las pompas de la lengua (Bécquer, 2000: 646). La labor libertadora de Bécquer, parece deducirse de las palabras de Cernuda, aún está por continuar. Si la poesía moderna se inicia con el Romanticismo y el Romanticismo fue entre nosotros, con la excepción de Bécquer, el eco de un eco, es necesario enraizar en la otra tradición abierta por los románticos ingleses y alemanes.

Traer el auténtico Romanticismo a España implicaba para Cernuda traer la verdadera poesía moderna, instalarla entre nosotros, que casi no la habíamos conocido. No deja de llevar mucha razón Silver cuando se pregunta cómo tuvo que desarrollarse nuestro Romanticismo para que un «romántico ejemplar» se diera en la Espańa de la primera mitad del siglo XX (Silver, 1996: 12). Saltando por encima de casi un siglo de poesía española Cernuda decide empeñarse, como advirtió Gil de Biedma (1977: 350), en una «insólita acción de retaguardia»: la de revivir desde sus orígenes la tradición romántica española, la de refundarla y recrearla. La inmersión a partir del exilio en la línea de la poesía meditativa inglesa, iniciada modernamente con Wordsworth, no será sino una consecuencia lógica de todo este proceso (Valente, 1994; Insausti, 2000; Hugues, 1987; Díez de Revenga, 1988: 236).

Otro texto de 1935, «Palabras antes de una lectura», presenta el conflicto entre realidad y deseo en términos que deben mucho al Romanticismo alemán y al inglés, al Romanticismo nórdico en definitiva, y no tanto al francés o español. La insatisfacción del deseo proviene de la imposibilidad de anegarse en el «vasto cuerpo de la creación», de fundirse con la hermosura del mundo. Para entonces Cernuda dice experimentar una corriente simultánea y opuesta dentro de sí, de atracción y de hostilidad hacia lo real. La realidad atrae al deseo, pero la posesión de aquélla sólo puede ser precaria; de aquí la corriente contraria, de hostilidad hacia el «irónico atractivo» de la realidad:

Puesto que, según parece, ésa o parecida ha sido también la experiencia de algunos filósofos y poetas que admiro, con ellos concluyo que la realidad exterior es un espejismo y lo único cierto mi propio deseo de poseerla. Así, pues, la esencia del problema poético, a mi entender, la constituye el conflicto entre realidad y deseo, entre apariencia y verdad, permitiéndonos alcanzar alguna vislumbre de la imagen completa del mundo que ignoramos, de la «idea divina del mundo que yace al fondo de la apariencia», según la frase de Fichte. (Cernuda, 1935b: 602) 
No parece difícil identificar a estos poetas y filósofos que el autor admira, sin duda románticos. Schopenhauer, al que el joven Cernuda leyó junto a Nietzsche (Cernuda, 1978: 30), presenta el deseo (el conatus spinozista) como la gran fuerza motriz del mundo. La idea schopenhaueriana de que el sujeto se encuentra atravesado por una oscura e insaciable voluntad de vivir que apenas se puede concretar, de suerte que acaba condenándolo a «un constante suplicio tantálico en el que la realidad se revela elusiva, inasible» (Insausti, 2000: 131), también la experimentan a su modo Shelley o Blake. En cualquier caso, la aspiración a vislumbrar la unidad del mundo (la «sustancia única» de Spinoza) por debajo de las apariencias, evidente en la mención que hace Cernuda de Fichte, nos conduce a lo que se ha llamado la lucha del héroe por conquistar el Único (Argullol, 1982), a la Naturphilosophie que presta singularidad y tragedia a los románticos alemanes e ingleses, de Novalis o Hölderlin a Keats, pero también al italiano Leopardi, que leyó Cernuda bajo el ruido de los cañones que bombardeaban Madrid.

\section{LA FASCINACIÓN POR EL SUR}

No debe extrañar que Silver haya proyectado sobre Cernuda la misma problemática que Heidegger proyecta sobre Hölderlin: la poesía cernudiana como cuestionar metafísico, como búsqueda del «Ser como Naturaleza» y de la «Naturaleza como Ser», Ser que se halla perdido desde que se ha consumado la separación del Origen, donde latía la unidad de los contrarios, de realidad y deseo (Silver, 1990: 69). De aquí, como en Hölderlin, la fascinación por la Antigüedad clásica, visible sobre todo en Invocaciones, porque «lo vedado al presente allí se daba libremente, lo que ahora se nos muestra escindido era, en aquel tiempo mítico, unidad de belleza y libertad» (Argullol, 1990: 149). Es lo que Marí ha llamado el «idealismo trascendental» de Cernuda, remitiendo ahora a Kant.

Conviene tener en cuenta la idea de que la tradición poética española no sólo amordazaba a Cernuda, sino que además retardaba el momento de llegar a ser el poeta que sabía que era; Hölderlin, el Romanticismo nórdico en general, no fueron un azar en el camino de Cernuda. Llegó a ellos como consecuencia de la necesidad de salir de un tradición que consideraba cegada e impedía la "cristalización de la poesía española contemporánea» (Marí, 1990: 172). En esta otra tradición descubre la razón que le impele a la escritura, el «fundamento del poetizar», que radica en el aludido conflicto ente realidad y deseo, entre apariencia y verdad. La pérdida de la antigua unidad del cosmos, de la armonía, ha conducido a la oposición trágica, a la 
«irreversible escisión entre el yo y el mundo, entre el deseo del yo y la realidad del mundo, entre la idea que el yo tiene del mundo y la realidad real que el mundo manifiesta. El poeta ya no puede exaltar la unidad del mundo, ni la identificación del yo y del mundo» (Marí, 1990: 173). No puede exaltarla, pero sí recrearla en determinados instantes a través de la escritura, haciendo uso de la «imaginación trascendental», la facultad que según Kant actúa sin necesitar la percepción sensible: «Esa imaginación, independiente de la experiencia, muestra al hombre la constitución originaria del ser» (p. 174). Si al poeta sólo le queda la posibilidad de recrear idealmente la unidad perdida, el Ser originario, nos encontramos, en términos de Schiller que también valen para Cernuda (Insausti, 2000: 167), con un poeta sentimental (o lo que es lo mismo: romántico) frente al poeta ingenuo, antiguo, imitativo, que no vive la escisión con la Naturaleza.

Nadie más ingenuo, lógicamente, siempre en este preciso sentido schilleriano, que el niño. No otra cosa explica la identificación de la infancia con un paraíso mítico y original, anterior al desgarro que imponen el tiempo, la historia y la muerte, anterior en definitiva a la "caída" (Silver, 1996: 79114). Es el mismo planteamiento que se observa en el Alberti de Sobre los ángeles, en el Lorca de Poeta en Nueva York o el Aleixandre de Sombra del paraíso (Real Ramos, 1983: 47). Las interpretaciones de los poemas en prosa de Ocnos (Ramos Ortega, 1982 y 1990; Valender, 1984) han ido todas en esta dirección: la recreación de la infancia sevillana como imagen del Edén antes de que se produjera el exilio, metafísico por supuesto, porque como ha recordado Luis Antonio de Villena en varias ocasiones (1990 y 1991), Cernuda ya era un desterrado antes de abandonar Espańa con motivo de la guerra civil, y ello por su naturaleza de poeta romántico.

«No me buscarías si no me hubieses encontrado»: la frase de Pascal que cita Cernuda (1978: 46) en "Historial de un libro» ilustra perfectamente que el estudio de la poesía inglesa al que se entrega a partir de entonces, y particularmente la del siglo XIX, sobre la que publicará un libro en 1958, no vino sino a confirmar la Weltanschauung que ya estaba en su práctica poética y teórica. Por eso resulta de algún modo artificial la división que se ha establecido en la crítica cernudiana entre quienes defienden una interpretación "mitográfica» o mística, incluso bucólico-pastoril, y quienes defienden una lectura ética o edificante de la «biografía espiritual» (Paz, 1977) que es La realidad y el deseo. Tanto Harris (1992: 33-34) como Silver (1996: 10-11) han terminado hablando de «reconciliación» y "consenso» entre una y otra línea interpretativa.

El ejemplo de Luis Cernuda para la poesía del 50 (Gil de Biedma, 1962; Talens, 1990; Jiménez Millán, 2002) y para buena parte de la poesía que ha 
venido después no resulta del todo comprensible, en efecto, sin la prehistoria de su insatisfacción romántica. El llamado «último Cernuda», aquel que se adhiere a la llamada poesía de la experiencia y de la reflexión moral, hunde sus pies en el poeta moderno que se acoge a una tradición del Romanticismo distinta a la espańola. O por decirlo de otra manera, el poeta romántico del sur mítico se completa con el poeta meditativo del norte. Recordando su salida definitiva de España, Cernuda escribe lo siguiente: «No conocía Inglaterra, aunque fuera país que desde mi niñez me interesó, sin duda por esa atracción de contrarios que tan necesaria es en la vida, ya que la tensión entre ellos resulta, al menos para mí, fructífera: mi sur nativo necesitaba del norte, para completarme» (Cernuda, 1978: 45). Y un poco más adelante: «La luz, los árboles, las flores del paisaje inglés comenzaron a parecer en mis versos, para matizarlos con un colorido y claroscuro nuevos. Así fue el norte completando en mí, meridional, la gama de emociones sensoriales» (p. 48).

Bajo esta tensión de contrarios entre el norte y el sur construye Cernuda su imagen de Andalucía, su andalucismo nórdico como ideología estética entre las diversas posibilidades del poetizar moderno que ofrece el Veintisiete. Claro que este andalucismo nórdico se aviene a la perfección con la matriz romántica de la que venimos hablando. En el trabajo de 1935 sobre Bécquer relaciona las Leyendas con los cuentos de Hoffmann para sentenciar que la «línea nórdica» de aquél tiene sus afinidades naturales, si no electivas (Cernuda, 1935a: 77). No es una simple nota al paso porque hace hincapié en esta línea nórdica, considerándola constante y decisiva en el caso que le ocupa. Los antepasados de Bécquer vinieron de Flandes a Sevilla en el siglo XVII y algo de aquella tradición debió de quedar, porque «su obra es poco andaluza en el sentido fácil de la frase» (Cernuda, 1978: 79). Existe en el corazón mismo de Andalucía una veta más honda, grave y retirada que la que se estima ordinariamente. Lo más puro de Andalucía sigue una línea parecida a la de Bécquer: «Tal vez ella nos explique el espíritu nórdico de Bécquer, si entendemos como nórdica precisamente esa profundidad solitaria». Cernuda percibe con claridad que la originalidad de las Rimas procede de la fusión del intimismo germánico a la manera de Heine con lo popular. Pero ya encontramos la primera distancia con respecto al andalucismo fácil o folklórico, de superficie. La conexión de esa Andalucía honda con el espíritu nórdico de Bécquer se revela como fundamental si pensamos en que para Cernuda el romanticismo becqueriano escapa al «desierto de palabras» en que consiste la poesía española. Al igual que en Cernuda, en Bécquer el sur nativo se completa con el norte. Resulta bastante sintomático que el primero describa los sueños juveniles en Sevilla del segundo como los de un indolente: 
Pocas tierras se prestan como Andalucía a ese deseo indolente; la naturaleza no necesita allí que se le ańada nada por nuestro espíritu, sino al contrario: es nuestro espíritu quien debe anegarse en ella, como el nadador fatigado que se deja llevar por las olas. Lo que sorprende allá siempre es la falta de esfuerzo. Pero los dioses ciegan a quien quieren perder. Y Bécquer no veía aquella tierra; sólo atendía a un afán que le impulsaba hacia distinto ambiente. (Cernuda, 1935a: 73-74)

Parece claro que Cernuda ha comenzado a experimentar su propia fascinación por el sur, en consonancia con la mitología de lo meridional que aprende en Gide y con la atracción que sintieron anteriormente los románticos del norte. Los orígenes de la crisis romántica no surgen en los tres países del sur de Europa, España, Italia y Grecia, sino en Alemania, Inglaterra y más tarde Francia. No podía darse el estallido romántico allí donde no se habían impuesto previamente el racionalismo y la Ilustración: «No es pues el Sur de donde parte el grueso tronco romántico. Pero sí podemos decir, por contra, que es hacia él que se inclinan algunas de sus ramas más fecundas. La fascinación del Sur juega una función de primerísimo orden en el desarrollo de la sensibilidad romántica» (Argullol, 1987: 174). Los románticos del norte descubren en el sur un mundo situado al margen de la civilización burguesa, una escapatoria al mal d'esprit originado por el tiempo y el país en que les ha tocado vivir. El sur fue ante todo una "operación literaria». Basta pensar en la imagen medieval y caballeresca de España que obtienen de la lectura de nuestros clásicos del Siglo de Oro autores como Herder, Goethe, Schiller o los hermanos Schlegel. La atracción romántica de España se asienta además en una visión orientalizante, justificada sobre todo por Andalucía (Azúa, 1989), y en el ideal de conciliación entre hombre y Naturaleza, escindidos en la mentalidad del Romanticismo originario como queda dicho. Que la realidad de Espańa tuviera poco que ver con las escapatorias de la imaginación romántica es lo de menos. La transfiguración literaria de España servía a las necesidades estéticas e ideológicas del pensamiento romántico: la creación consoladora de un universo onírico para negar la normalidad de un mundo mediocre. El romántico viaja al sur, con la imaginación o en la práctica, «no porque allí pueda encontrar un mundo alternativo, sino porque puede forjarse la ilusión de que está negando el suyo» (Argullol, 1987: 181). Así ocurre con el Luis Cernuda que pone sus ojos allá en el sur, como consuelo para escapar de sus amigos, de su familia, de su país. En la geografía irreal y fantástica del sur confluyen realidad y deseo.

Hasta qué punto el sur es un territorio sin anclaje fijo, una geografía imaginaria dictada por el deseo, lo pone de manifiesto el poema «Quisiera 
estar solo en el sur», perteneciente a Un río, un amor (1929). En él se lee este verso: «En el sur tan distante quiero estar confundido». El propio Cernuda explica en "Historial de un libro» que el título de este poema surgió de la consulta a un catálogo de discos de jazz y no de la nostalgia de Andalucía (Cernuda, 1978: 36). No es el sur nativo el que trasluce detrás de este poema sino el sur norteamericano, vislumbrado también a través de la movilidad del cine (García Montero, 2000: 246). Pero, si no como «expresión nostálgica», Andalucía se superpone en no pocas ocasiones a ese sur en que se desea estar confundido. Sólo que se trata de una Andalucía transmutada poéticamente por los ojos de quien ha encontrado en el norte el complemento del sur natal. En su artículo de 1931 sobre Moreno Villa la Andalucía que llama la atención de Cernuda tiene mucho que ver con la que unos años después describe a propósito de Bécquer:

¿Qué embrujamiento detiene mi espíritu en tal atmósfera, manteniéndolo allá como en su único país? No puedo ni deseo vivir en otro lado; todos serían hostiles y más bajos. Aquella atmósfera es la lejana Andalucía. Andalucía, ya se sabe, es el Norte de España; pero no la busquéis en parte alguna, porque no estará allí. Andalucía es un sueño que varios andaluces llevamos dentro. Nada sabemos de la otra, la baja Andalucía, ni de sus modas chillonas y vanidad (Cernuda, 1931: 28)

Norte y sur, más que complementarse, ahora se confunden. Únicamente desde la geografía del deseo se puede sostener que Andalucía es el norte de España. No debe buscarse en los mapas porque no existe en parte alguna; es una construcción de los poetas andaluces, de Moreno Villa, Prados o Aleixandre, los compañeros que Cernuda cita. Pero también de Lorca y Alberti, que estilizan lo popular andaluz (Rodríguez, 2001; García Montero, 1996; Soria Olmedo, 1990) alejándolo del costumbrismo y del pintoresquismo más o menos folklóricos, de Bizet a los hermanos Álvarez Quintero (Cózar, 1993). No hay más que pensar en el Lorca que define su Romancero gitano como un libro «antipintoresco, antifolklórico, antiflamenco», porque en él no está expresada la Andalucía que se ve, pero está temblando la que no se ve (García Lorca, 1998: 150). Justo como ocurre en el Cernuda que destaca la Andalucía honda de Bécquer o que rechaza la Andalucía baja de las modas chillonas, complacida de sí misma. Desde el Poema del cante jondo al Romancero gitano Lorca traza una geografía poética semejante que divide a Andalucía en dos, la Andalucía del llanto, la Andalucía de la pena negra, que coincide aproximadamente con su parte oriental, y la Andalucía occidental, la Andalucía alegre de la desembocadura del Guadalquivir: Sevilla es ciudad para herir, Córdoba y Granada son ciudades para morir bajo el ala negra de 
la tragedia. Molesto con el mito de su gitanismo, Lorca define su Romancero gitano como el "poema de Andalucía» y ve en el gitano lo más aristocrático de su país, ya que "guarda el ascua, la sangre y el alfabeto de la verdad andaluza universal».

La aristocracia del pueblo y la verdad andaluza universal llevan a pensar de inmediato en Juan Ramón Jiménez, de quien aprenden en primera instancia los jóvenes del 27 la estilización del populismo (Rodríguez, 1994). Cansado de la celebración casticista de Castilla por el Noventayocho, Juan Ramón decidió exaltar Andalucía a lo universal, alejándose asimismo de la Andalucía cantada por los «complacedores de turistas» (Jiménez, 1982: 298-299). Que incluyera a Lorca entre ellos, junto a Gautier y Rueda, no deja de ser una de las notorias injusticias de Juan Ramón con los jóvenes poetas a los que guió en sus comienzos. Porque el mismo Lorca, en carta de 1922 a Fernández Almagro, también da por concluido el mito poético de Castilla y confiesa su voluntad de escribir una "obra popular y andalucísima» (García Lorca, 1997: 148). Es en todo este magma poético, de sustitución de la ideología en crisis del Noventayocho por los nuevas programas de la vanguardia modernizadora en España, donde hay que situar el andalucismo nórdico de Cernuda.

No se extrae otra conclusión de la reseña que José Bergamín realiza en 1927 de Perfil del aire, una de las pocas críticas favorables que recibió este primer libro. Para Bergamín la "trascendencia estética universal de Andalucía» que se ha afirmado con la poesía de Juan Ramón Jiménez, la música de Falla y la pintura de Picasso ha influido decisivamente en los nuevos artistas, andaluces o no. En Salinas descubre la asimilación por un poeta castellano de esta «idealidad andaluza»; incluso en las «cristalizaciones poéticas» de Jorge Guillén aprecia un "platónico amor andalucista». Bergamín intenta deshacer con sus argumentos la excesiva semejanza que la «crítica parecidista» ha encontrado entre la poesía guilleniana y la del joven Cernuda, pero también rompe la falsa aproximación que se ha establecido, ya en 1927, entre Lorca y Alberti, porque si el primero viene de lo popular, naturalmente, como un resultado, el segundo va hacia lo popular con intención artística, para inventarlo. Sea como fuere, lo cierto es que Perfil del aire queda inserto en la línea de ese «idealismo andaluz» que ha abierto Juan Ramón en el proceso de la «nueva evolución lírica en España» (Bergamín, 1978: 180).

\section{EL IDEAL PARADISÍACO}

Otro andalucismo, alejado de la poesía pura y de la lección de Juan Ramón Jiménez, mucho más cercano a las exigencias del romanticismo nórdico cernudiano, es el que encontramos en la «Divagación de la 
Andalucía romántica», publicada en 1936 en la revista Cruz y Raya, que dirigía Bergamín. Andalucía funciona entonces como metáfora del paraíso perdido:

Confesaré que sólo encuentro apetecible un edén donde mis ojos vean el mar transparente y la luz radiante de este mundo; donde los cuerpos sean jóvenes, oscuros y ligeros; donde el tiempo se deslice insensiblemente entre las hojas de las palmas y el lánguido aroma de las flores meridionales. Un edén, en suma, que para mí bien pudiera estar situado en Andalucía. (Cernuda, 1936: 83)

Desde luego estas palabras funcionan como un eco de las escritas para la poética del 34, o de las escritas a propósito de Moreno Villa y después Bécquer. Lo curioso es que la imagen de la Andalucía romántica que se forja Cernuda (Bellón Cazabán, 1978; García Baena, 1982; González Troyano, 1990; García Montero, 2002) dialoga con la Teoría de Andalucía esbozada por Ortega y Gasset unos años antes, en una serie de artículos aparecidos en El Sol (1927). El propósito de un texto y otro, de cualquier modo, no puede ser más distinto.

Ortega comienza su ensayo señalando que durante todo el siglo XIX España ha vivido sujeta a la influencia hegemónica de Andalucía; después el centro de gravedad se trasladó al norte, hasta que España ha comenzado de nuevo a saturarse de influencia septentrional, con el consiguiente retorno a lo andaluz. Dejando de lado lo que llama la «quincalla meridional» (el contrabandista, el cante hondo, la presunta alegría del andaluz), Ortega considera llegado el momento de preguntarse por «lo misterioso, lo profundo de Andalucía», que sitúa más allá de esa "farsa multicolor que sus habitantes ponen ante los ojos de los turistas» (Ortega, 1984: 233). Pues los andaluces sufren de la propensión a «representarse y ser mimos de sí mismos», a darse como espectáculo a los extraños. Es la primera coincidencia con la visión que tiene Cernuda de Andalucía. Recordemos que a propósito de Bécquer rechazaba el andalucismo fácil y exterior. Ahora, en su divagación, reacciona contra la falsa ola de tradición renovadora que ha disfrazado a Sevilla en los últimos tiempos como para un carnaval:

Pero no es más andaluz quien de andaluz se disfraza, sino quien lleva intacto dentro de sí, límpido y seductor, el reflejo de esta tierra misteriosa, perezosa y activa, vívida y sońadora. ¿Qué relación tiene lo otro con Andalucía? Preferibles son mil veces las ruinas, fieles siempre, a ese absurdo y externo andalucismo reciente, de una facilidad repugnante. Vergüenza de todos los gestos, gritos, coplillas y escenas vulgares, compuestas a imitación de algo que nunca fue real. (Cernuda, 1936: 97) 
La misma distancia con respecto al colorismo andalucista que la existente en Lorca o Alberti, la misma estilización. La diferencia radica en que lo andaluz se estiliza no a partir del neopopularismo que hace uso de las imágenes de vanguardia sino a partir de la herida romántica.

Tanto Ortega como Cernuda quieren rascar en el disfraz de sí mismo que se coloca el andaluz, ver qué hay debajo de esa Andalucía de primeros términos. Ortega hace descansar su teoría en lo que llama el «ideal vegetativo». $\mathrm{El}$ andaluz vive en una tierra ubérrima, que da espléndidos frutos sin apenas esfuerzo. La consecuencia es que el andaluz ha hecho de la holgazanería la "fórmula de su cultura», entendida esta última como solución que damos al problema de la vida. Nunca está más cerca Ortega del tópico peligroso, por mucha que sea la seriedad filosófica de la que trata de revestirse:

Podrá en el andaluz ser la pereza también un defecto y un vicio; pero, antes que vicio y defecto, es nada menos que su ideal de existencia. Esta es la paradoja que necesita meditar todo el que pretenda comprender a Andalucía: la pereza como ideal y como estilo de vida. Si sustituimos el vocablo pereza por su equivalente «mínimo esfuerzo", la idea no varía, y cobra, en cambio, un aspecto más respetable (Ortega, 1984: 240).

El andaluz ha reducido el problema vital al mínimo, ha llegado al ideal de vita minima, porque «en vez de esforzarse para vivir, vive para no esforzarse, hace de la evitación del esfuerzo principio de su existencia». Si la pereza, como argumenta Ortega de la mano de F. Schlegel, es el postrer residuo que nos queda del paraíso, Andalucía constituye «el único pueblo que permanece fiel al ideal paradisíaco de la vida» (p. 241). La delicia básica del andaluz consiste en gozar de la "temperie deleitable». No es que no haga otra cosa que vegetar, es que pule el plano vegetativo de la existencia. La indolencia como fórmula de cultura y la vita minima como ideal de existencia tienen un claro eco en la «Divagación de la Andalucía romántica». No es sino Ortega quien se dibuja detrás de estas palabras:

Con lo ya creado no necesita más la satisfacción y goce humanos. ¿A qué esforzarse, pues? La naturaleza es tan rica allí que sus dones debían bastar generosamente a quienquiera. Ha sido necesaria la feroz civilización burguesa para que el hombre del pueblo andaluz se viera desposeído en un ambiente donde todo respira, al contrario, abundancia y descuido. Poco bastaría allá para la dicha inconsciente. Sé de un árabe tan pobre que sólo poseía, como cosas superfluas, una guitarrilla, un ave enjaulada y una maceta de albahaca. Sentado por la mañana en una roca sobre el mar, tendía su aparejo de pesca que 
le procuraba el mínimo alimento cotidiano; y allí, entre el trinar del ave, el perfume de la albahaca y sus propios sueńos, que acompańaba a veces con la guitarra, dejaba pasar los días, cuyo semblante para él no era otro sino el mismo uniformemente feliz de su desinterés sonriente. Y esta actitud vital, ¿̨no es puramente romántica? Por lo menos ése es el romanticismo indolente que el ambiente andaluz nos inspira. (Cernuda, 1936: 83-84)

Recordemos que en el artículo sobre Bécquer, que también ve la luz en Cruz y Raya un año antes, ya Cernuda lo presenta como un indolente y destaca la falta de esfuerzo que caracteriza a Andalucía. Pero estas ideas venían de antiguo. La narración titulada «El indolente», de 1929, que no debe confundirse con el poema en prosa del mismo título publicado en el suplemento literario de La Verdad en 1926 (Jiménez Millán, 2001; Ramos Ortega, 2002), sitúa la acción en Sansueńa, un imaginario pueblo del litoral andaluz al que llega un arqueólogo inglés, Don Míster, en busca de una estatua sumergida en el mar. Sansueńa es descrita con todos los atributos de un paraíso mítico, en el que se cierra la herida entre realidad y deseo: «En Sansueńa los ojos se abren a una luz pura y el pecho respira un aire oloroso. Ningún deseo duele al corazón, porque el deseo ha muerto en la beatitud de vivir» (Cernuda, 1929b: 270).

La lectura de las reflexiones orteguianas sobre Andalucía acaba articulándose con el idealismo romántico y trascendental de Cernuda. No en balde Silver se ha servido de los conceptos de «ideal vegetativo" y de vita minima para trazar la trayectoria que va desde Ocnos a Variaciones sobre tema mexicano, desde el intento de recrear el paraíso andaluz de la niñez tras su pérdida, salvando el "abismo ontológico», al maridaje entre realidad y deseo que se produce al contacto con la tierra mexicana, que actúa como trasunto de la Andalucía nativa (Silver, 1996: 167-209). Pero la interpretación de Silver no sólo sigue de cerca a Ortega, también al Wordsworth para quien "el nińo es el padre del hombre», una idea de la que se hace eco Cernuda en «Historial de un libro»; la niñez, para Wordsworth, es el territorio de la inmortalidad porque permite ser uno con el mundo. Semejante mitología de la infancia se aprecia en Shelley, Coleridge, Blake o en el Hölderlin de Hiperión (Insausti, 2000: 72-80). Paralelamente, la imagen paradisíaca de la indolencia que Cernuda encuentra en Ortega se refuerza con la que le ofrecerán los románticos ingleses, por ejemplo Keats, que ve en ella una estrategia contra el dualismo entre espíritu y naturaleza (Insausti, 2000: 141-147).

La indolencia ya estaba presente en los poemas de Perfil del aire y todavía en Como quien espera el alba se incluye un poema titulado, otra vez, «El 
indolente». Teniendo muy presente que Ortega justifica la pereza del andaluz en su fidelidad al ideal paradisíaco de la vida, en la atmósfera vegetal que lo envuelve, Vivanco afirma que lo más romántico de Cernuda es «su pasividad o abandono y, concretando más, su indolencia o pereza en la palabra» (Vivanco, 1957: 300). Habría que matizar mucho esta supuesta pereza o abandono pasivo a la palabra. Además no es únicamente Ortega quien le sugiere a Cernuda ese «romanticismo indolente» que en 1936 encuentra en el ambiente andaluz. No hay que olvidar por supuesto a los viajeros románticos, algunos de los cuales se mencionan a lo largo de texto: «romántico y anónimo viajero sentimental, lejano hermano mío", escribe Cernuda parafraseando como en alguna otra ocasión al Baudelaire de Las flores del mal; la «Divagación» comienza, además, con una cita de Las aventuras del último Abencerraje, de Chateaubriand, en la que se hace explícita la imagen del paraíso. El propio Vivanco señala que fue «un poeta andaluz y sevillano, Bécquer, el primero entre nosotros en hacer el elogio de la pereza y considerarla como residuo paradisíaco y regalo de los dioses» (Vivanco, 1957: 314). Aunque Cernuda dice interesarse por el romanticismo consustancial a la tierra andaluza, y no por el romanticismo literario en relación con Andalucía, no deja de advertir el origen andaluz de Bécquer, «nuestro poeta romántico más considerable». Las leyendas becquerianas recrean ambientes extraños a la tierra del poeta, pero «su andalucismo, sutil como un hálito, baña profundamente cualquier atmósfera que descubra»; y así Toledo o Veruela, Aragón o Castilla, quedan reflejados en "su irisado vidrio de andaluz nórdico» (Cernuda, 1936: 86).

Indudablemente lo que el propio Cernuda llama un poco más adelante el «andalucismo nórdico» de Bécquer resulta fundamental en su búsqueda de otra tradición romántica, la anglogermánica, distinta a la francesa y la española. Pues en la "Divagación" se deja bien claro que el Romanticismo tuvo un origen nórdico y «del norte bajó al sur» persiguiendo el sol y la languidez meridionales. Los románticos buscaban en Andalucía la tradición árabe (la Alhambra de Granada, la Mezquita de Córdoba, el Alcázar de Sevilla), el exotismo orientalista, pero sobre todo «una salvaje libertad vital, cosa desconocida en sus países originarios, ya aferrados entre las garras de una civilización burguesa» (Cernuda, 1936: 88). Merece la pena subrayar con trazo grueso estas palabras porque en 1933, con la incorporación a la revista revolucionaria Octubre, ha culminado en Cernuda la actitud de repudio hacia la sociedad burguesa iniciada en sus textos surrealistas. Más tarde la idealización de España se confundirá con la memoria de Andalucía en varios poemas del exilio y Sansueńa también será entonces el lugar de la indolencia, del ocio y la contemplación que oponer al horrible mundo práctico del norte gobernado por el capitalismo, la lógica de lo útil, la falta 
de reposo (Harris, 1992: 128-136; Silver, 1996: 241-246; Sánchez Rosillo, 1992: 149; Insausti, 2000: 146-147).

Pero volviendo a la «Divagación» no debemos pasar por alto que se establece de nuevo una divisoria entre quienes visitan o posan sus ojos en Andalucía y quienes los detienen en Italia o Grecia, entre un Hugo o un Chateaubriand de un lado, y un Shelley, un Keats e incluso un Byron de otro: «Pero es preciso reconocerlo, faltó a Andalucía en esa época el prestigio hondo y sutil que infiltraron a la atmósfera italiana los poetas ingleses y alemanes» (Cernuda, 1936: 89). Al igual que para estos otros románticos, Andalucía es para Cernuda el paraíso que se echa de menos «desde las horribles ciudades modernas" y a la vez la tierra que "parece conciliar, por una rara armonía, contrapuestos extremos» (p. 90). No sólo anula, pues, el conflicto entre Naturaleza y Civilización sino además el conflicto entre realidad y deseo. Es el lugar en el que se produce la coincidencia de los opuestos, el lugar del Uno o de la «felicidad». La distancia con respecto al fácil andalucismo no puede ser mayor.

No mueven a Cernuda el «afán andalucista» o lo que llama la «pintoresca tontería» del costumbrismo a lo Fernán Caballero. Otra vez el alejamiento del andalucismo folklórico es claro. Resulta por eso sorprendente que muchos ańos después, en 1962, reconociera que «cierta ańoranza vergonzante del ambiente andaluz» le llevó durante su estancia en Nueva Inglaterra a releer el teatro de los Quintero, dado su gusto no confesado hasta entonces por la imagen que éstos ofrecen de la realidad andaluza. Pero Cernuda avisa del peligro que yace en esta visión de Andalucía: recuerda que ya Unamuno se preguntó qué quedaría de la obra de los Quintero si se tradujera del andaluz. $\mathrm{Su}$ receptividad ante el teatro de los Quintero, acaba admitiendo Cernuda (1962: 729), acaso se deba al hecho de ser andaluz él también.

No parece que en la "Divagación sobre la Andalucía romántica» haya habido hueco para esta mirada benevolente, dada la "vergüenza» que se experimenta ante la Andalucía disfrazada de sí misma. La estilización de lo popular andaluz asoma en el momento en que Cernuda perfila el itinerario romántico, de Granada a Córdoba, de Córdoba a Sevilla, de Sevilla a Cádiz. Al detenerse en Sevilla, la ciudad natal que abandona en 1928 cansado de ella (Cernuda, 1978: 34; Aleixandre, 1978), encuentra dos claves románticas: Murillo y Mañara; el primero es, como Bécquer, otro "andaluz nórdico», "exquisitamente andaluz y exquisitamente popular». No muy lejos del neopopularismo, Cernuda añade que la verdadera elegancia española está en el pueblo y en él tienen que buscarla los artistas. Descuido, ocio, voluptuosidad, dejadez, muelle abandono al ambiente, son las características que adornan la vida andaluza. La pregunta que a estas alturas 
de la «Divagación» se hace Cernuda (“¿Será ése nuestro edén perdido?») confirma nuevamente la condición de exiliado romántico que hasta aquí hemos intentado poner de relieve.

\section{BiBLIOGRAFÍA}

Aleixandre Vicente, «Luis Cernuda deja Sevilla», Litoral («Homenaje a Luis Cernuda»), 1978, 79-81, pp. 184-186.

Argullol Rafael, El Héroe y el Único. El espíritu trágico del Romanticismo, Madrid, Taurus, 1982.

- «La fascinación del sur», Territorio del nómada, Madrid, Fondo de Cultura Económica, 1987, pp. 173-181.

- «Las palabras y los muros. La misión del poeta en la obra de Luis Cernuda», en Cortines, 1990, pp. 143-150.

Azúa Félix de, «El mito de la Andalucía romántica», El aprendizaje de la decepción, Pamplona, Pamiela, 1989, pp. 145-158.

Bécquer Gustavo Adolfo, Rimas. Otros poemas. Obra en prosa (introd., ed. y notas de Leonardo Romero Tobar), Madrid, Espasa Calpe, 2000.

Bellón Cazabán Juan Alfredo, «La Andalucía de Luis Cernuda. Apuntes y divagaciones sobre los mitos edénicos y demás paraísos naturales y artificiales», Letras del Sur, 1978, 3-4, pp. 32-36.

Bergamín José, «El idealismo andaluz», Litoral («Homenaje a Luis Cernuda»), 1978, 79-81, pp. 180-182.

Carnero Guillermo, "Luis Cernuda y el purismo poético: Perfil del aire», Las armas abisinias. Ensayos sobre literatura y arte del siglo XX, Barcelona, Anthropos, 1989, pp. 199-211.

Cernuda Luis, «Paul Éluard» (1929a), en Cernuda, 2002, III, pp. 15-17.

- «El indolente» (1929b), en Cernuda, 2002, III, pp. 270-303.

- «José Moreno Villa o los andaluces en España» (1931), en Cernuda, 2002, III, pp. 25-29.

- «Bécquer y el Romanticismo español» (1935a), en Cernuda, 2002, III, pp. 6681.

- «Palabras antes de una lectura» (1935b), en Cernuda, 2002, II, pp. 601-606.

- «Divagación sobre la Andalucía romántica» (1936), en Cernuda, 2002, III, pp. 82-102.

- «Los Quintero» (1962), en Cernuda, 2002, II, pp. 722-730.

- "Historial de un libro (La realidad y el deseo)», Litoral ("Homenaje a Luis Cernuda»), 79-81, 1978, pp. 27-61.

- «Poética», en Antología de Gerardo Diego. Poesía española contemporánea (ed. de Andrés Soria Olmedo), Madrid, Taurus, 1991, pp. 580-581 y 752-754. 
- Obra completa (ed. de Derek Harris y Luis Maristany), Madrid, Siruela, 3 vols., 2002, $2^{\text {a }}$ ed.

Cortines Jacobo (ed.), Actas del Primer Congreso Internacional sobre Luis Cernuda (1902-1963), Sevilla, Universidad de Sevilla, 1990.

Cózar Rafael de, «Andalucía y la generación del 27», Cuadernos Hispanoamericanos, 1993, 514-515, pp. 319-321.

Díez de Revenga Francisco Javier, Panorama crítico de la generación del 27, Madrid, Castalia, 1988.

García Miguel Ángel, El Veintisiete en vanguardia. Hacia una lectura histórica de las poéticas moderna y contemporánea, Valencia, Pre-Textos, 2001.

García Baena Pablo, «Divagación sobre la Andalucía de Luis Cernuda», Fin de Siglo, 1982, 1, pp. 23-25.

García Lorca Federico, «Imaginación, inspiración, evasión», Conferencias II (ed. de Mario Hernández), Madrid, Alianza, 1984, pp. 11-31.

- Epistolario completo (ed. de Andrew A. Anderson y Christopher Maurer), Madrid, Cátedra, 1997.

- "Conferencia-recital del Romancero gitano», en Federico García Lorca, Romancero gitano (ed. de Mario Hernández), Madrid, Alianza, 1998, pp. 149159.

García Montero Luis, "García Lorca y el cante jondo", La palabra de Ícaro. Estudios literarios sobre García Lorca y Alberti, Granada, Universidad de Granada, 1996, pp. 41-62.

- «Luis Cernuda y la soledad compartida», El sexto día. Historia intima de la poesía española, Madrid, Debate, 2000, pp. 235-257.

- «Luis Cernuda y Andalucía», en Luis Cernuda 1902-1963, Madrid, Publicaciones de la Residencia de Estudiantes, 2002, pp. 89-106.

Gil de Biedma Jaime, "El ejemplo de Luis Cernuda» (1962), en Gil de Biedma, 1994, pp. 63-68.

- «Como en sí mismo al fin» (1977), en Gil de Biedma, 1994, pp. 339-353.

- El pie de la letra. Ensayos completos, Barcelona, Crítica, 1994.

González Troyano Alberto, «Entre la divagación y el sueño: la Andalucía romántica», en Cortines, 1990, pp. 33-37.

Harris Derek, La poesía de Luis Cernuda, Granada, Universidad de Granada, 1992.

Hughes Brian, Luis Cernuda and the Modern English Poets, Alicante, Universidad de Alicante, 1987.

Insausti Gabriel, La presencia del Romanticismo inglés en el pensamiento poético de Luis Cernuda, Pamplona, Ediciones de la Universidad de Navarra, 2000.

Jiménez Juan Ramón, Política poética (ed. de Germán Bleiberg), Madrid, Alianza, 1982.

Jiménez Millán Antonio, "La prosa de Luis Cernuda. Antecedentes de Ocnos», Promesa y desolación. El compromiso en los escritores de la generación del 27, Granada, Universidad de Granada, 2001, pp. 41-51. 
- «Luis Cernuda en la poesía española contemporánea», en Luis Cernuda 19021963, Madrid, Publicaciones de la Residencia de Estudiantes, 2002, pp. 109134.

Mainer José-Carlos, "Alrededor de 1927: Historia y cultura en torno a un canon", Historia, literatura, sociedad (y una coda española), Madrid, Biblioteca Nueva, 2000, pp. 333-353.

Marí Antoni (ed.), El entusiasmo y la quietud. Antología del Romanticismo alemán, Barcelona, Tusquets, 1979 .

- «Del idealismo trascendental en Luis Cernuda», en Cortines, 1990, pp. 171175.

Ortega y Gasset José, Teoría de Andalucía, en María Zambrano-José Ortega y Gasset, Andalucía. Sueño y realidad, Granada, Biblioteca de la Cultura Andaluza, 1984, pp. 231-245.

- La deshumanización del arte y otros ensayos de estética, Madrid, Revista de Occidente-Alianza Editorial, 1993, 8a ed.

Paz Octavio, «La palabra edificante», en Harris Derek (ed.), Luis Cernuda, Madrid, Taurus, 1977, pp. 135-160.

Ramos Ortega Manuel José, La prosa de Luis Cernuda. El libro "Ocnos», Sevilla, Diputación Provincial de Sevilla, 1982.

- «Y allí Luis Cernuda», en Cortines, 1990, pp. 165-169.

- «Un recorrido por la prosa de Luis Cernuda», en Luis Cernuda 1902-1963, Madrid, Publicaciones de la Residencia de Estudiantes, 2002, pp. 137-152.

Real Ramos César, Luis Cernuda y la generación del 27, Salamanca, Ediciones de la Universidad de Salamanca, 1983.

Rodríguez Juan Carlos, «Juan Ramón o la ciudad de pesadilla. De la forma como estilización a la forma como vida", Lorca y el sentido, Madrid, Akal, 1994, pp. 103-117.

- «El mito de la poesía comprometida: Rafael Alberti», La norma literaria, Madrid, Debate, 2001, pp. 281-316.

Salinas Pedro, «Luis Cernuda, poeta», Literatura española siglo XX, Madrid, Alianza, 2001, pp. 227-236.

Sánchez Rosillo Eloy, La fuerza del destino. Vida y poesía de Luis Cernuda, Murcia, Universidad de Murcia, 1992.

Silver Philip W., «Cernuda ¿poeta romántico?», en Cortines, 1990, pp. 61-70. - Luis Cernuda: el poeta en su leyenda, Madrid, Castalia, 1996.

Soria Olmedo Andrés, Vanguardismo y crítica literaria en España, Madrid, Istmo, 1988.

- «La depuración de la mirada. En torno al neopopularismo en Rafael Alberti», Cuadernos Hispanoamericanos, 485-486, 1990, pp. 109-118.

Talens Jenaro, «Lecturas de Luis Cernuda desde la generación de 1950», en Cortines, 1990, pp. 51-60.

Valender James, Cernuda y el poema en prosa, Londres, Tamesis, 1984. 
Valente José Ángel, «Luis Cernuda y la poesía de la meditación», Las palabras de la tribu, Barcelona, Tusquets, 1994, pp. 111-123.

Villena Luis Antonio de, «El último Cernuda», en Cortines, 1990, pp. 139-142. - «Luis Cernuda, entre el exilio y sus metáforas», en Cernuda Luis, Las Nubes. Desolación de la Quimera, Madrid, Cátedra, 1991, 3a ed., pp. 11-57.

Vivanco Luis Felipe, "Luis Cernuda en su palabra vegetal indolente», Introducción a la poesía española contemporánea, Madrid, Guadarrama, 1957, pp. 295-338. 